\title{
ANALISIS PENGARUH SHIFT KERJA TERHADAP BEBAN KERJA MENTAL PADA OPERATOR DISTRIBUTED CONTROL SYSTEM (DCS) DENGAN METODE NASA-TAKS LOAD INDEX (TLX) (Studi Kasus: PT. Cahaya Fajar Kaltim)
}

\author{
Riko Ardhi Surya, Lina Dianati Fathimahhayati, Farida D. Sitania \\ Program Studi Teknik Industri, Fakultas Teknik, Universitas Mulawarman \\ Jalan Sambaliung No. 9, Kampus Gunung Kelua, Samarinda 75119 \\ Email: richardhi0101@gmail.com
}

\begin{abstract}
ABSTRAK
PT Cahaya Fajar Kaltim merupakan perusahaan yang bergerak dalam bidang pembangkit listrik tenaga uap (PLTU). Pada tanggal 26 Maret 2003 merupakan awal resminya PT. Cahaya Fajar Kaltim yang beroperasi di daerah Embalut, Tanjung Batu, Tenggarong Seberang, Kutai Kartanegara Kalimantan Timur. Sistem produksi yang digunakan di PT Cahaya Fajar Kaltim menggunakan sistem otomasi sehingga semua proses produksi dilakukan secara terpusat dengan menggunakan piranti elektronik berupa komputer di area Distributed Control System (DCS). Karena sifatnya yang vital, menjadikan area DCS rentan terhadap resiko yang berdampak besar.Di area DCS, para operator dituntut dalam memantau dan memberikan keputusan yang tepat disaat kondisi darurat.Kondisi ini membuat beban kerja mental yang dirasakan oleh operator tinggi. Pengukuran beban kerja mental pada penelitian ini menggunakan metode NASA- Taks Load Indexs (TLX) dengan mempertimbangkan 3 kondisi kerja yang berbeda yaitu shift pagi pada pukul 07.00-15.00, shift siang pada pukul 15.00-23.00, dan shift malam pada pukul 23.00-07.00. Hasil penelitian menunjukan bahwa beban kerja mental yang diperoleh operator boiler di area DCS didapat pada shift pagi termasuk ke dalam kategori beban kerja mental tinggi dengan nilai skor sebesar 55,89, pada shift siang termasuk ke dalam kategori beban kerja mental agak tinggi dengan nilai skor sebesar 49,41, dan pada shift malam termasuk ke dalam kategori beban kerja mental tinggi dengan nilai skor sebesar 60,52. Berdasarkan metode NASA-TLX shift kerja yang paling tingi dirasakan operator boiler di (DCS) PT.CFK adalahshift malam yang disebabkan oleh menurunnya daya konsentrasi karena rasa mengantuk, kemudian shift pagi yang disebabkan banyaknya tugas yang diberikan meliputi input data, kontroling, dan pengawasan namun operator bisa menyesuaikan kondisi, kemudian terakhir pada shift siang hari sama kondisinya dengan shift pagi namun banyaknya tugas jauh berkurang tugas hanya meliputi kontroler dan pengawasan. Rekomendasi dapat diberikan terhadap hasil nilai perhitungan dan analisa beban kerja mental operator boilerDistributed Control System (DCS) di PT.Cahaya Fajar Kaltim yaitu dengan menerapkan sistem shift baru, menyediakan tempat istirahat yang memadai, membangun fasilitas dan prasarana pendukung, dan juga memberikan pelatihan keamanan kerja yang rutin.
\end{abstract}

Kata Kunci: $\quad$ Distributed Control System (DCS), Beban Kerja Mental, Shift Kerja, NASA- Taks Load Indexs (TLX)

\section{PENDAHULUAN}

\section{Latar Belakang}

Dalam dunia kerja, kesehatan dan keselamatan kerja merupakan aspek yang sangat penting untuk diperhatikan oleh perusahaan. Berdasarkan undang-undang ketenagakerjaan Nomor 13 Tahun 2003, pada pasal 86 ayat 2 menyebutkan perlunya diselenggarakan upaya keselamatan kerja di dalam suatu perusahaan untuk melindungi keselamatan pekerja/buruh guna mewujudkan produktivitas kerja yang optimal. Berdasarkan UU No.1 Tahun 1970 Pasal 2 Ayat 1, tentang keselamatan kerja adalah sarana utama untuk mencegah kecelakaan, cacat, dan kematian sebagai akibat kecelakaan kerja. Keselamatan kerja yang dimaksud tidak hanya sebatas pencegahan tetapi juga upaya untuk melindungi tenaga kerja secara menyeluruh di lingkungan industri atau perusahaan.

Ergonomi sebagai ilmu yang peduli akan adanya keserasian manusia dan pekerjaannya. Ilmu ini menempatkan manusia sebagai unsur pertama, terutama kemampuan, kebolehan, dan batasannya. Ergonomi bertujuan membuat pekerjaan, peralatan, informasi, dan lingkungan yang serasi satu sama lainnya, dengan menganalisis hubungan fisik antara manusia 
dengan fasilitas kerja. Manfaat dan tujuan ilmu ini adalah untuk mengurangi ketidaknyamanan pada saat bekerja. Dengan demikian Ergonomi berguna sebagai media pencegahan terhadap kelelahan kerja sedini mungkin sebelum berakibat kronis dan fatal.

PT. Cahaya Fajar Kaltim merupakan perusahaan yang bergerak dalam bidang Pembangkit Listrik Tenaga Uap (PLTU) terletak di daerah Desa Tanjung Batu Kecamatan Tenggarong Seberang Kabupaten Kutai Kartanegara Propinsi Kalimantan Timur. PT. Cahaya Fajar Kaltim menghasilkan listrik dengan kapasitas total sebesar $110 \mathrm{MW}$ dengan 3 unit pembangkit, unit 1,2 dan 3. Di area ini tuntutan akan ketelitian sangat diperlukan, karena banyaknya tombol kontrol di area DCS sehingga memerlukan tingkat konsentrasi yang tinggi terutama pada control pembakaran batubara (boiler). Karena sifatnya yang vital menjadikan area DCS rentan terhadap resiko yang berdampak besar dalam proses produksi dan resiko keselamatan kerja maupun resiko kerusakan unit pembangkit. Halhal tersebut menjadi alasan pentingnya pengukuran beban kerja bagi para operator DCS. Dengan aktivitas yang monoton di setiap saat memungkinkan timbulnya beban kerja yang dialami operator semakin tinggi karena para operator bekerja untuk mengontrol stabilitas produksi. Kondisi seperti ini dapat menurunkan kondisi operator baik secara fisik dan terutama pada kondisi psikisnya.

Berdasarkan permasalahan tersebut makan dilakukan penelitian yang bertujuan untuk mengukur beban kerja mental operator Distribution Control System (DCS) khususnya operator boiler yang selama ini belum pernah dilakukan oleh perusahaan maupun peneliti lain. Salah satu metode yang dapat digunakan yaitu National Aeronautics and Space AdministrationTask Load Index (NASA-TLX). NASA-TLX merupakan pengukuran beban kerja mental dilakukan secara subyektif. Menurut Hart dan Staveland (1988), dalam NASA-TLX terdapat enam dimensi untuk menentukan ukuran beban kerja meliputi kebutuhan mental, kebutuhan fisik, tekanan waktu, pencapaian kinerja, usaha, dan tingkat stress. Pengukuran yang dilakukan juga mempertimbangkan faktor pembagian jam kerja shift. Pada penelitian ini pengukuran dengan menggunakan NASA-TLX mempertimbangkan shift kerja yang diharapkan mendapat hasil yang maksimal dari factor-faktor penyebab terjadinya beban kerja. Guna mengetahui pengaruh antar kondisi kerja (shift) penelitian ini mengunakan uji statistika yaitu Repeated Measures Anova. Melalui penelitian ini diharapkan dapat mengukur pengaruh beban kerja mental yang terjadi pada masing-masing operator boiler pada Distribution Control System (DCS). Selain itu, diberikan pula rekomendasi perbaikan, baik secara manajemen atau fasilitas prasarana sehingga menghasilkan perbaikan kondisi kerja pada PLTU Cahaya Fajar Kaltim khususnya diarea DCS yang lebih baik dan dapat menekan terjadinya beban kerja mental yang berlebih guna meminimbulkan resiko terjadinya kecelakaan kerja bagi manusia maupun unit di Distribution Control System (DCS).

\section{TINJAUAN PUSTAKA Pembangkit Listrik}

Pembangkit listrikadalah bagian dari alat industri yang dipakai untuk memproduksi dan membangkitkan tenaga listrik dari berbagai sumber tenaga, seperti PLTS, PLTB, PLTU, PLTA, PLTG, PLTN, PLTPB, PLTMH, PLTPS, dan PLTGL. Bagian utama dari pembangkit listrik ini adalah generator, yakni mesin berputar yang mengubah energi mekanis menjadi energi listrik dengan menggunakan prinsip medan magnet dan penghantar listrik. Mesin generator ini diaktifkan dengan menggunakan berbagai sumber energi yang sangat bemanfaat dalam suatu pembangkit listrik.

\section{Distributed Control System (DCS)}

Annafi (2010) menerangkan bahwa DCS adalah untuk meningkatkan efisiensi biaya serta reliability equipment pada perusahaan. Sistem kontrol yang lama dalam menangani suatu kontrol proses dipandang kurang efisien dari segi biaya maupun reliabilitynya. Penggunaan Distributed Control System (DCS) atau sistem kontrol yang terdistribusi, sudah sangat umum pada industry yang berukuran besar dan kompleks. Perkembangan teknlogi instrumentasi mulai dari manual, penumatik sampai elektrik yang berbasis komputer memungkinkan kita untuk lebih meringkas tugas pengawasan, mencatat secara manual terhadap harga penunjukan suatu alat ukur. 


\section{Ergonomi}

Menurut Nurmianto (2004), Istilah ergonomi berasal dari bahasa latin yaitu "Ergon" dan "Nomos" (hukum alam) dan dapat didefinisikan sebagai studi tentang aspek - aspek manusia dalam lingkungan kerjanya yang ditinjau secara anatomi, fisiologi, psikologi, engineering, managemen dan desain atau perancangan. Ergonomi berkenaan pula dengan optimasi, efisiensi, kesehatan, keselamatan dan kenyamanan manusia di tempat kerja, di rumah, dan tempat rekreasi. Di dalam ergonomi dibutuhkan studi tentang ergonomi dimana manusia, fasilitas kerja dan lingkungannya saling berinteraksi dengan tujuan utama yaitu menyesuaikan suasana kerja dengan manusianya. Definisi ergonomi dapat dilakukan dengan menjabarkannya dalam fokus, tujuan, dan pendekatan mengenai ergonomi.

1. Secara fokus

Ergonomi memfokuskan diri pada manusia dan interaksinya dengan produk, peralatan, fasilitas, prosedur, dan lingkungan dimana sehari-hari manusia hidup dan bekerja.

2. Secara tujuan

Tujuan ergonomi ada 2, yaitu peningkatan efektivitas dan efisiensi kerja, serta peningkatan nilai-nilai kemanusiaan seperti peningkatan keselamatan kerja, pengurangan rasa lelah.

3. Secara pendekatan.

Pendekatan ergonomi adalah aplikasi informasi mengenai keterbatasanketerbatasan manusia, kemampuan, karakteristik tingkah laku, dan motivasi untuk merancang prosedur dan lingkungan tempat aktivitas manusia tersebut sehari-hari.

\section{Beban Kerja Mental}

Dewasa ini aktiitas mental lebih banyak didominasi oleh pekerja-pekerja kantor, supervisor dan pimpinan sebagai pengambil keputusan dengan tanggung jawab yang lebih besar, pekerja dibidang teknik informasi, siagaan tinggi, pekerjaan yang bersifat montoni. Menurut Grandjean (1993) setiap aktifitas mental akan selalu melibatkan unsur persepsi, interpretasi, dan proses mental dari suatu keputusan atau proses mengingat informasi yang lampau. Yang menjadi masalah pada manusia adalah kemampuan untuk memanggil kembali atau mengingat informasi yang disimpan. Proses mengingat kembali ini sebagian besar menjadi masalah bagi orang tua. Seperti kita tahu bahwa kebanyakan mengalami penurunan daya ingat (Tarwaka, 2011).

Evaluasi beban kerja mental merupakan poin penting didalam penelitian dan pengembangan hubungan antara manusia-mesin, mencari tingkat kenyamanan, kepuasan, efisiensi dan keselamatan yang leih baik di tempat kerja, sebagaimana halnya yang menjadi target capaian implementasi ergonomi. Dengan maksud untuk mejamin keselamatan, kesehatan, kenyamanan dan efisiensi dan produktiittas jangka panjang bagi pekerja.

\section{Nasa TLX (Task Load Index)}

Metode NASA-TLX (National Aeronautics and Space Administration Task Load Index) merupakan metode yang digunakan untuk menganalisis beban kerja mental yang dihadapi oleh pekerja yang harus melakukan berbagai aktivitas dalam pekerjaannya. Metode NASA TLX dikembangkan oleh Sandra G. dari NASAames research center dan Lowell E. Staveland dari San Jose state university pada tahun 1981. Metode ini di kembangkan berdasarkan munculnya kebutuhan pengukuran subjektif yang terdiri dari skala Sembilan faktor ( Kesulitan tugas, tekanan waktu, jenis aktivitas, usaha fisik, usaha mental, performansi, frustasi, stress dan kelelahan). Dari Sembilan faktor ini disederhanakan lagi menjadi 6 yaitu Kebutuhan Mental demand (MD), Physical demand (PD), Temporal demand (TD), Performance (P), Frustation level (FR).Model ini dikembangkan oleh badan penerbangan dan ruang angkasa Amerika Serikat (NASA Ames Research Center).NASATask Load Index adalah prosedur rating multi dimensional, yang membagi workload atas dasar rata-rata pembebanan enam (6) subskala adalah sebagai berikut:

1. Kebutuhan fisik (Physical Demand). Seberapa besar aktivitas fisik yang dibutuhkan (misalnya: mendorong, menarik, memutar, mengendalikan, dan mengkatifkan)

2. Kebutuhan Mental (Mental Demand). Seberapa tinggi aktivitas mental dan perceptual dibutuhkan (misalnya: berpikir, memutuskan, menghitung, menghapal, 
melihat, dan mencari). Apakah tugas tersebut sederhana atau kompleks, mudah atau sulit.

3. Kebutuhan Waktu (Temporal Demand). Seberapa tertekankah anda karena batas waktu yang diberikan untuk mengerjakan tugas tersebut. Apakah kecepatan kerja anda rendah/tinggi.

4. Performansi (Performance). Seberapa sukseskah anda dalam mencapai tujuan pekerjaan yang telah ditetapkan dalam eksperimen. Puaskah anda dengan pekerjaan yang telah anda hasilkan.

5. Usaha (Effort).Seberapa keras anda harus bekerja (secara fisik dan mental) untuk mencapai tingkat performansi yang telah anda capai.

6. Tingkat Stres (Frustation Level). Seberapa terganggu, bosan, menjengkelkan, atau stress anda, saat mengerjakan tugas tersebut.

\section{Prosedur NASA TLX}

Hancock dan Meshkati (1988) merupakan salah satu peneliti yang dapat menjelaskan langkahlangkah dalam pengukuran beban kerja mental dengan menggunakan metode NASA-TLX, yaitu:

1. Penjelasan Indikator Beban Mental yang Akan Diukur Indikator

Tabel 1. Indikator Beban Mental

\begin{tabular}{|c|c|c|c|}
\hline No & Dimensi & Deskripsi & $\begin{array}{c}\text { Skala } \\
\text { Rating }\end{array}$ \\
\hline 1 & $\begin{array}{l}\text { Tuntutan } \\
\text { Mental } \\
\text { (Mental } \\
\text { Demand) }\end{array}$ & $\begin{array}{l}\text { Seberapa besar tututan } \\
\text { aktivitas metal dan } \\
\text { perseptual yang dibutuhkan } \\
\text { dalam pekerjaan (contoh: } \\
\text { berpikir, memutuskan, } \\
\text { menghitung, mengingat, } \\
\text { melihat, mencari) Apakah } \\
\text { pekerjaan tsb mudah atau } \\
\text { sulit, sederhana atau } \\
\text { kompleks, longgar atau } \\
\text { ketat? }\end{array}$ & $\begin{array}{l}\text { Rendah } \\
\text {-Tinggi }\end{array}$ \\
\hline 2 & $\begin{array}{l}\text { Tuntutan Fisik } \\
\text { (Physical } \\
\text { Demand) }\end{array}$ & $\begin{array}{l}\text { Seberapa besar aktiitas fisik } \\
\text { yang dibutuhkan dalam } \\
\text { pekerjaan (contoh: } \\
\text { mendorong, menjalankan, } \\
\text { dan lainnya). Apakah } \\
\text { pekerjaan tersebut mudah } \\
\text { atau sulit, pelan atau cepat, } \\
\text { tenang atau buru-buru? }\end{array}$ & $\begin{array}{l}\text { Rendah } \\
\text {-Tinggi }\end{array}$ \\
\hline 3 & $\begin{array}{l}\text { Tuntutan } \\
\text { Waktu } \\
\text { (temporary } \\
\text { Demand) }\end{array}$ & $\begin{array}{l}\text { Seberapa besar tekanan } \\
\text { waktu yang dirasakan selama } \\
\text { pekerjaan atau elemen } \\
\text { pekerjaan berlangsung? } \\
\text { Apakah pekerjaan perlahan } \\
\text { dan santai, atau cepat dan } \\
\text { melelahkan? }\end{array}$ & $\begin{array}{l}\text { Rendah } \\
\text {-Tinggi }\end{array}$ \\
\hline
\end{tabular}

\begin{tabular}{|c|c|c|c|}
\hline 4 & $\begin{array}{l}\text { Performansi } \\
(\text { Own } \\
\text { Performance })\end{array}$ & $\begin{array}{l}\text { Seberapa besar keberhasilan } \\
\text { di dalam mencapai target } \\
\text { pekerjaan? Seberapa puas } \\
\text { performansi di dalam } \\
\text { mencapai target tersebut? }\end{array}$ & $\begin{array}{l}\text { Baik- } \\
\text { Jelek }\end{array}$ \\
\hline 5 & $\begin{array}{l}\text { Tingkat Usaha } \\
\text { (Effort) }\end{array}$ & $\begin{array}{l}\text { Seberapa besar usaha yang } \\
\text { dikeluarkan secara mental } \\
\text { dan fisik yang dibutuhkan } \\
\text { untuk mencapai level } \\
\text { performansi }\end{array}$ & $\begin{array}{l}\text { Rendah } \\
\text {-Tinggi }\end{array}$ \\
\hline 6 & $\begin{array}{l}\text { Tingkat } \\
\text { Frustasi } \\
\text { (Frustation) }\end{array}$ & $\begin{array}{l}\text { Seberapa besar rasa tidak } \\
\text { aman, putus } \\
\text { tersinggung, terganggu, } \\
\text { dibandingkan } \\
\text { perasaan aman, puas, } \\
\text { nyaman, dan kepuasan diri } \\
\text { yang dirasakan selama } \\
\text { mengerjakan pekerjaan } \\
\text { tersebut? }\end{array}$ & $\begin{array}{l}\text { Rendah } \\
\text {-Tinggi }\end{array}$ \\
\hline
\end{tabular}

2. Pembobotan Pada bagian ini responden diminta untuk memilih salah satu dari dua indikator yang dirasakan lebih dominan menimbulkan beban kerja mental terhadap pekerjaan tersebut. Kuisioner NASA-TLX yang diberikan berbentuk perbandingan berpasangan yang terdiri dari 15 perbandingan berpasangan. Jumlah tally ini kemudian akan menjadi bobot untuk tiap indikator beban mental.

\section{Tabel 2. Perbandingan berpasangan NASA} TLX

\begin{tabular}{|c|l|l|}
\hline NO & \multicolumn{2}{|c|}{ PERBANDINGAN BERPASANGAN } \\
\hline $\mathbf{1}$ & Tingkat Usaha (TU) & Performance (P) \\
\hline $\mathbf{2}$ & Kebutuhan Waktu (KW) & Tingkat Frustasi (TF) \\
\hline $\mathbf{3}$ & Kebutuhan Waktu (KW) & Tingkat Usaha (TU) \\
\hline $\mathbf{4}$ & Kebutuhan Fisik (KF) & Tingkat Frustasi (TF) \\
\hline $\mathbf{5}$ & Performance (P) & Tingkat Frustasi (TF) \\
\hline $\mathbf{6}$ & Kebutuhan Fisik (KF) & Kebutuhan Waktu (KW) \\
\hline $\mathbf{7}$ & Kebutuhan Fisik (KF) & Performance (P) \\
\hline $\mathbf{8}$ & Kebutuhan Waktu (KW) & Kebutuhan Mental (KM) \\
\hline $\mathbf{9}$ & Tingkat Frustasi (TF) & Tingkat Usaha (TU) \\
\hline $\mathbf{1 0}$ & Performance (P) & Kebutuhan Mental (KM) \\
\hline $\mathbf{1 1}$ & Performance (P) & Kebutuhan Waktu (KW) \\
\hline $\mathbf{1 2}$ & Kebutuhan Mental (KM) & Tingkat Usaha (TU) \\
\hline $\mathbf{1 3}$ & Kebutuhan Mental (KM) & Kebutuhan Fisik (KF) \\
\hline $\mathbf{1 4}$ & Tingkat Usaha (TU) & Kebutuhan Fisik (KF) \\
\hline $\mathbf{1 5}$ & Tingkat Frustasi (TF) & Kebutuhan Mental (KM) \\
\hline
\end{tabular}

3. Pemberian Rating Pada bagian ini responden diminta memberi rating terhadap keenam indikator beban mental. Rating yang diberikan adalah subjektif tergantung pada beban mental yang dirasakan oleh responden tersebut. Rating yang diberikan adalah subjektif tergantung pada beban mental yang dirasakan oleh responden tersebut.Untuk mendapatkan skor beban mental NASATLX, bobot dan rating untuk setiap indikator dikalikan kemudian dijumlahkan dan dibagi 
15 (jumlah perbandingan berpasangan). Berdasarkan skala Rating Sheet pada metode NASA-TLX mengunakan skala dari 0 sampai 100 , nilai 0 berada pada range I rendah (low) dan nilai 100 berada pada range tinggi (higt). Kategori ini digunakan sebagai nilai pengali pada bobot yang diambil dari hasil wawancara berikut merupakan contoh rating sheet Gambar 1.

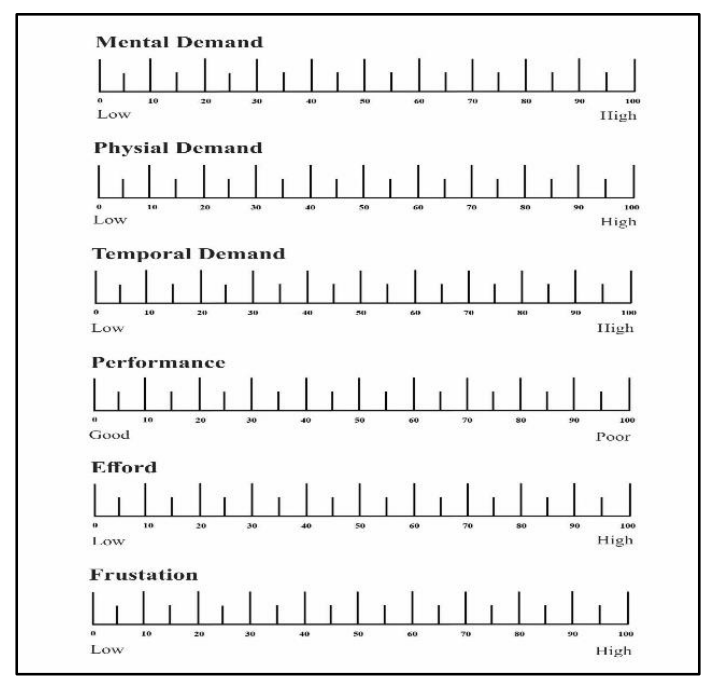

Gambar 1Rating Sheet NASA-TLX

Berdasarkan penjabaran yang didapat pada meteri NASA-TLX berikut ini merupakan langkah mengola data yang dapat dijelaskan adalah sebagai berikut:

a. Menghitung Produk

Produk diperoleh dengan cara mengalika rating dengan faktor untuk masingmasing deskriptor. Dengan demikian dihasilkan 6 nilai produk untuk 6 indikator (KM,KW,KF,P,TU, dan TF)

Produk $=$ Rating $\times$ Bobot kerja

b. Menghitung Weighted Workload (WWL) WWL diperoleh dengan cara menjumlahkan keenam nilai produk $\mathrm{WWL}=\sum$ produk

c. Menghitung Rata-rata WWL

Rata-rata WWL diperoleh dengan cara membagi WWL dengan bobot total.

$$
\text { Skor }=\frac{\left.\sum \text { (bobot }^{*} \text { rating }\right)}{15}
$$

d. Interpretasi Nilai Skor

Berdasarkan penjelasan Hart dan Staveland (1981) dalam teori Nasa-TLX, skor beban kerja yang diperoleh dapat diintepretasikan sebagai berikut:

1) Nilai Skor $>80$ menyatakan beban pekerjaan berat

2) Nilai Skor 50 - 79 menyatakan beban pekerjaan sedang

3) Nilai Skor < 50 menyatakan beban pekerjaan ringan.

Berdasarkan pengkategorian penjelasan Hart dan Staveland (1981) dalam teori Nasa-TLX kemudian disempurnakan oleh Simanjuntak (2010), kategori beban kerja mental diklarifikasikan menjadi lima indikator sebagai berikut:

1) Nilai skor 0-9 menyatakan beban kerja rendah

2) Nilai skor 10-29 menyatakan beban kerja sedang

3) Nilai skor 30-49 menyatakan beban kerja agak tinggi

4) Nilai skor 50-79 menyatakan beban kerja tinggi, dan

5) Nilai skor 80-100 menyatakan beban kerja tinggi sekali.

Berdasarkan beberapa interpretasi nilai skor tersebut pengklasifikasian terhadap beban kerja mental dapat lebih mudah dan sederhana. Nilai skor ini merupakan nilai akhir yang digunakan untuk menganalisa ke tahap selanjutnya.

\section{Uji Normalitas}

Menurut Rini (2015), bahwa sebagian besar penelitian dalam bidang statistika berhubungan dengan pengujian asumsi distribusi, baik secara teori maupun praktik di lapangan. Salah satu pengujian asumsi distribusi yang paling sering digunakan adalah pengujian asumsi kenormalan, artinya menguji apakah sampel data yang digunakan memiliki distribusi normal atau tidak. Distribusi normal merupakan distribusi yang paling penting dalam statistika untuk berbagai alasan. Analisis data statistika secara parametrik sangat memerlukan asumsi kenormalan. Banyak literatur yang telah membahas tentang uji-uji normalitas. Referensi merupakan salah satu literatur yang membahas tentang berbagai uji normalitas dan prosedurnya. Referensi mengkaji 
tentang uji normalitas yang diperoleh berdasarkan metode Bayesian, yaitu dengan melihat perbedaan atau ketidaksesuaian antara sampel pengamatan dan sampel prediksi yang berasal dari distribusi posterior prediktif. Referensi membahas perbandingan power dari uji Kolmogov-Smirnov, uji Shapiro-Wilk, uji Liliefors, dan uji Anderson-Darling.

\section{Uji Anova Repeated Measures Anova}

Menurut Suaib (2011), Repeated Measures Anova (RMA) adalah analisis varian yang menganalisis suatu variabel yang diamati secara berulang pada periode/waktu yang berbeda. Teladan dari pengertian ini seperti pengamatan tinggi tanaman, diameter batang, panjang sulur, jumlah daun, jumlah anakan, dan lain sebagainya yang dilakukan secara berkala pada umur 1,2,3, 4, 5, dan 6 minggu setelah tanam (MST). Sesungguhnya, secara teoritis RMA telah diperkenalkan dan diuraikan sejak lama oleh Steel dan Torrie (1960) yang ia sebut sebagai "Split-Plot in Time Experiment". Akan tetapi, jenis analisis ini masih jarang diterapkan di Indonesia karena alasan yang tidak jelas. Padahal, hasil analisis ini jauh lebih mudah diinterpretasikan dan lebih akurat sesuai tujuan penelitian yang ingin dicapai. Hampir setiap buku teks Statistika menguraikan cara RMA dengan nama atau istilah yang berbeda selain yang diuraikan oleh Steel dan Torrie (1960). Akan tetapi yang umum dipakai adalah analisis varian pengamatan berulang (Repeated Measurement Anova) sebagaimana diuraikan oleh Mead et al. (1994), Motulsky, (1995), Zar, (1999), Clewer dan Scarisbrick (2001), dan Johnson dan Wichern (2007). Bahkan, sejak lama artikel review di jurnal internasional juga sudah diulas oleh beberapa pakar dengan nama RMA, dua di antaranya seperti: Huynh dan Feldt (1970) dalam Journal of American Statistic Association 65:1582-1589, dan Litle (1989) dalam jurnal HortScience 24(1):37-40. Seperti beberapa anova lainnya, anova pengukuran berulang digunakan untuk menguji kesamaan antar rerata.

\section{METODOLOGI PENELITIAN Objek Penelitian}

Objek penelitian ini dilakukan di PT. Cahaya Fajar Kaltim, khususnya di bagian DCS
(Distribution Control Sistym) dan mengambil data pada operator boiler pada unit 3. Dalam hal ini berarti terdapat 3 shift yang akan diukur masing-masing beban kerja dari total 9 operator boiler.

\section{Pengolahan Data}

Tahap pengolahan data dilakukan setelah diperoleh data-data dari hasil pengumpulan data. Pengolahan data yang dilakukan berdasarkan pada tinjauan pustaka. Pada penelitian ini data diperoleh pegukuran beban kerja menggunakan NASA- TLX (Task Load Index)

1. Pengukuran Beban Kerja Mental Secara Subjektif

Pengukuran beban kerja mental secara subjektif merupakan pengukuran yang digunakan untuk mengukur beban kerja mental yang dialami oleh operator boiler di area distribution control system (DCS), berikut merupakan langkah-langkah pengukuran kerja beban kerja mental secara subjektif menggunakan NASA-TLX:

a. Melakukan Pembobotan

Pada tahap ini responden diminta untuk memberikan tanda silang diantara dua indikator yang telah dipasangkan yang mana dirasakan lebih dominan dalam menimbulkan beban kerja mental ketika melaksanakan tugasnya. Kuisioner Nasa - Task Load Index yang diberikan berbentuk perbandingan berpasangan yang terdiri dari 15 perbandingan berpasangan. Dari kuisioner ini dihitung tally dari setiap indikator yang dirasakan paling berpengaruh. Jumlah tally ini kemudian akan menjadi bobot untuk tiap indikator beban mental.

b. Melakukan Pemberian Rating

Berdasarkan tahap ini pemberian Rating pada bagian ini responden diminta memberi rating terhadap keenam indikator beban mental. Rating yang diberikan adalah subjektif tergantung pada beban mental yang dirasakan oleh responden tersebut. rating yang diberikan adalah subjektif tergantung pada beban mental yang dirasakan oleh responden tersebut. Untuk mendapatkan skor beban mental NASA-TLX, bobot dan rating untuk setiap indikator 
dikalikan kemudian dijumlahkan dan dibagi 15 (jumlah perbandingan berpasangan.

c. Menghitung Produk

Berdasarkan tahap ini produk diperoleh dengan cara mengalikan rating dengan bobot faktor untuk masing-masing indikator.

d. Menghitung Weighted Workload (WWL) Tahap selanjutnya menghitungan Weighted Workload (WWL) diperoleh dengan menjumlahkan keenam nilai produk.

e. Menghitung rata-rata Weighted Workload (WWL)

Rata-rata Weighted Workload (WWL) diperoleh dengan membagi Weighted Workload (WWL) dengan jumlah bobot total.

f. Interpretasi Hasil Nilai Skor

Setelah perhitungan selesai dilakukan, langkah selanjutnya adalah menginterpretasi hasil nilai skor. Dalam kategori beban kerja, kategori skor beban kerja yang didapatkan terbagi dalam tiga bagian yaitu pekerjaan menurut para responden tergolong berat (nilai skor > 80 ), beban pekerjaan sedang (nilai skor antara 50-70), beban pekerjaan agak ringan (nilai $<50$ ).

2. Uji Normalitas Data

Uji normalitas data digunakan sebagai alat untuk mengetahui data yang telah terkumpul melalui hasil pengukuran sebelumnya telah terdistribusi normal atau tidak. Pada hasil uji normalitas ini sangat penting karena sangat berpengaruh pada pengujian statistika selanjutnya data dapat dikatakan normal jika Asymsig $>a(0,05)$ dan sebaliknya, jika data yang telah terkumpul telah terdistribusi normal maka langkah pengujian selanjutnya adalah menggunakan statistika parametric yaitu uji Repeated Measures Anova, sedangkan jika data yang telah didapat tidak terdistribusi normal maka menggunakan statistika non parametrik yaitu menggunakan uji Friedman.

3. Pengujian Repeated Measures Anova Berdasarkan penelitian ini pengujian menggunakan Repeated Measures Anova digunakan untuk mengetahui pengaruh shift kerja terhadap beban kerja mental operator boiler di area distribution control system dengan menggunakan software statistika yaitu SPSS 21. Sebelum masuk ke tahap analisis Repeated Measures Anova terlebih dahulu menguji tingkat variansi data yang digunakan dengan melihat nilai sperisitas, nilai sperisitas dianggap memenuhi jika sig $>a(0,05)$.

\section{Tahap Pembahasan dan Analisa}

Pada tahapan analisis data ini akan dilakukan analisis berdasarkan hasil yang diperoleh dari Nasa - Task Load Index pada operator boiler PLTU Embalut, mengidentifikasi beban kerja mental yang signifikan dilihat dari kebutuhan fisik, kebutuhan waktu, kebutuhan mental, performansi, usaha, dan tingkat frustasi yang dialami. Berdasarkan data tersebut maka akan diketahui prioritas yang perlu perbaikan dan beban kerja yang dominan dari pekerjaan operator boiler pada, masing-masing tahap dapat dijabarkan sebagai berikut:

1. Menganalisis Beban Kerja Mental Operator Secara Subjektif

Tahap analisis beban kerja mental secara subjektif ini digunakan untuk menganalisis beban kerja yang diperoleh operator boiler di area Distribution Cotrol System (DCS) dengan mengguanakan metode NASA-TLX pada 3 kondisi yang berbeda yaitu pada shift pagi, shift siang, dan shift malam.

2. Menganalisis Pengaruh Shift Kerja Terhadap Beban Kerja Mental

Tahap analisis pengaruh shift kerja terhadap beban kerja mental ini digunakan untuk menganalisis pengaruh yang timbul dari masing-masing shift kerja terhadap adanya beban kerja mental yang dialai oleh operator boiler di area Distribution Control System (DCS) yang diperoleh berdasarkan perhitungan pada pegujian denganmenggunakan uji Repeated Measures Anova.

3. Usulan Perbaikan dan rekomendasi

Usulan perbaikan dan rekomendasi dilakukan berdasarkan hasil yang telah didapat berdasarkan perolehan beban kerja mental yang paling dominan dalam menjalankan pekerjaan sebagai operator boiler di area DCS, sehingga dapat menekan resiko kerja yang dapat merugikan pekerja ataupun resiko kerusakan unit. 
Tahap Penutup dan Saran

Tahap penutup merupakan tahap akhir yang dilakukan dalam penelitian yang di dalamnya berisi kesimpulan dan saran. Kesimpulan diperoleh berdasarkan hasil analisis yang telah dilakukan. Sedangkan saran berfungsi sebagai acuan dalam pengembangan untuk penelitian selanjutnya dengan melengkapi kekurangan yang ada pada penelitian ini.

\section{HASIL DAN PEMBAHASAN}

\section{Pengukuran Beban Kerja Mental Shift Pagi.}

Berdasarkan tahap-tahap yang telah dilakukan, berikut merupakan hasil keseluruhan beban kerja mental yang telah diukur kepada seluruh operator boiler unit 3 PT. Cahaya Fajar Kaltim yang berjumlah 9 orang.Hasil perhitungan beban kerja mental dari kesembilan orang operator boiler PT. CFK dapat dilihat pada TAbel 3.

Tabel 3. Hasil Pengkategorian Beban Kerja Mental Operator boiler shift 1 (pagi)

\begin{tabular}{|c|c|c|c|c|c|c|c|c|c|}
\hline \multirow{2}{*}{$\begin{array}{c}\text { Nama } \\
\text { Operator }\end{array}$} & \multicolumn{6}{|c|}{ Indikator } & \multirow[t]{2}{*}{ Jumlah } & \multirow{2}{*}{$\begin{array}{c}\text { Rata-rata } \\
\text { (skor) }\end{array}$} & \multirow[b]{2}{*}{ Kategori } \\
\hline & KM & $\mathrm{KF}$ & KWW & $P$ & TU & TF & & & \\
\hline Operator 1 & 195 & 320 & 225 & 60 & 240 & 0 & 1040 & 69,33 & Tinggi \\
\hline Operator? & 240 & 160 & 70 & 100 & 210 & 80 & 860 & 1,9 & in: \\
\hline Operato & 210 & 0 & 100 & 40 & 210 & 150 & 710 & 4,25 & Agat ting \\
\hline Operator 4 & 200 & 210 & 150 & \begin{tabular}{|l|}
10 \\
\end{tabular} & 400 & 0 & 970 & 4,67 & Tinggi \\
\hline Operator 5 & 90 & 240 & \begin{tabular}{|l|}
150 \\
\end{tabular} & 80 & 70 & 30 & 660 & 44,00 & Agak tinggi \\
\hline Operator 6 & 360 & 400 & 30 & 0 & 150 & \begin{tabular}{|l|}
90 \\
\end{tabular} & 1030 & 68,67 & Tinggi \\
\hline Operator 7 & 210 & 0 & 150 & 140 & 110 & 150 & 760 & 8,67 & Tinggi \\
\hline Operator 8 & 200 & 70 & 110 & 40 & 180 & 0 & 600 & $\overline{000}$ & Agalk tinggi \\
\hline Operator 9 & 225 & 240 & 210 & 30 & 210 & 0 & 915 & 61,00 & Tinggi \\
\hline Total & 1930 & 1640 & 1195 & 500 & 1780 & 500 & 7545 & 503,00 & \\
\hline 2ata-rata & & & & & & & & 55,89 & Tinggi \\
\hline
\end{tabular}

\section{Pengukuran Beban Kerja Mental Shift Siang}

Pengukuran pada beban kerja mental berdasarkan pada kondisi shift siang melalui tahapan-tahapan perhitungan yang sama pada shift pagi yang meliputi pemberian kuesioner kepada kesembilan operator boiler unit 3 , dan didapatkan nilai masing-masing indikator yang dapat dilihat pada Tabel 4.
Tabel 4. Hasil Pengkategorian Beban Kerja Mental Operator boiler shift 2 (siang)

\begin{tabular}{|c|c|c|c|c|c|c|c|c|c|}
\hline \multirow{2}{*}{$\begin{array}{c}\text { Nama } \\
\text { Operator }\end{array}$} & \multicolumn{6}{|c|}{ Indikator } & \multirow[t]{2}{*}{ Jumlah } & \multirow{2}{*}{$\begin{array}{c}\begin{array}{c}\text { Rata-rata } \\
\text { (skor) }\end{array}\end{array}$} & \multirow[b]{2}{*}{ Kategori } \\
\hline & KM & $\mathrm{KF}$ & KW & $P$ & TU & TF & & & \\
\hline Operator 1 & 130 & 130 & 120 & 175 & 280 & 0 & 835 & 55,67 & Tinggi \\
\hline Operator 2 & 210 & 180 & 70 & 60 & 210 & 160 & 890 & 59,33 & Tinggi \\
\hline Operator 3 & 70 & 120 & 100 & 40 & 150 & 90 & 570 & 38,00 & Agak Tinggi \\
\hline Operator 4 & 350 & 50 & 210 & 0 & 280 & 0 & 890 & 59,33 & Tinggi \\
\hline Operator 5 & 40 & 30 & 80 & 150 & 120 & 50 & 470 & 31,33 & Agak Tinggi \\
\hline Operator 6 & 210 & 200 & 0 & 50 & 20 & 80 & 560 & 33 & Agak Tinggi \\
\hline Operator 7 & 75 & 165 & 195 & 140 & 120 & 140 & 835 & 55,67 & Tinggi \\
\hline Operator 8 & 55 & 210 & 450 & 140 & 140 & 0 & 995 & 66,33 & Tinggi \\
\hline Operator 9 & 180 & 80 & 150 & 15 & 160 & 0 & 585 & 41,67 & Agak Tinggi \\
\hline Total & 1320 & 1165 & 1375 & 770 & 1520 & 520 & 6670 & 444,67 & \\
\hline Rata-rata & & & & & & & & 49,41 & Agak Tinggi \\
\hline
\end{tabular}

\section{Pengukuran Beban Kerja Mental Shift Malam.}

Pengukuran pada beban kerja mental berdasarkan pada kondisi shift malam dan didapatkan nilai masing-masing indikator yang dapat dilihat pada Tabel 5.

\section{Tabel 5 Hasil Pengkategorian Beban Kerja Mental Operator boiler shift 2 (malam)}

\begin{tabular}{|c|c|c|c|c|c|c|c|c|c|}
\hline \multirow{2}{*}{$\begin{array}{c}\text { Nama } \\
\text { Operator }\end{array}$} & \multicolumn{6}{|c|}{ Indilikator } & \multirow{2}{*}{ Jumlah } & \multirow{2}{*}{$\begin{array}{c}\text { Rata-rata } \\
\text { (skor) }\end{array}$} & \multirow{2}{*}{ Kategori } \\
\hline & KM & KF & KW & $\mathrm{P}$ & $\mathrm{TU}$ & TF & & & \\
\hline Operator 1 & 50 & 100 & 40 & 180 & 80 & 180 & 630 & 42,00 & Agak Tingg \\
\hline Operator 2 & 140 & 320 & 0 & 140 & 210 & 140 & 950 & 63,33 & Tingg \\
\hline Operator 3 & 80 & 100 & 140 & 90 & 180 & 100 & 690 & 46,00 & Agak Tingg \\
\hline Operator 4 & 360 & 150 & 400 & 0 & 90 & 240 & 1240 & 82,67 & Tinggi Selal \\
\hline Operator 5 & 320 & 60 & 30 & 160 & 60 & 120 & 750 & 50,00 & Agak Tingg \\
\hline Operator 6 & 400 & 20 & 120 & 0 & 320 & 120 & 980 & 65,33 & Tingg! \\
\hline Operator 7 & 100 & 100 & 195 & 105 & 195 & 140 & 835 & 55,67 & inggl \\
\hline Operator 8 & 325 & 55 & 70 & 150 & 130 & 195 & 925 & 61,67 & Tinggl \\
\hline Pperator 9 & 360 & 340 & 270 & 20 & 180 & 0 & 1170 & 78,00 & Tinggi \\
\hline Total & 2135 & 1245 & 1265 & 845 & 1445 & 1235 & 8170 & 544,67 & \\
\hline Rata-rata & & & & & & & & 60,52 & Tinggi \\
\hline
\end{tabular}

\section{Uji Normalitas Data}

Konsep dasar dari uji normalitas adalah dengan membandingkan distribusi data yang akan diuji normalitasnya dengan distribusi normal baku. Distribusi normal baku adalah data yang telah ditransformasikan ke dalam bentuk Z-Score dan diasumsikan normal. Uji normalitas data ini dilakukan untuk mengetahui data yang telah dikumpulkan dengan menggunakan NASA-TLX telah terdistribusi normal atau tidak. Hasil yang didapat dari uji normalitas data ini sangat berpengaruh terhadap pengujian berikutnya, jika pada uji normalitas ini data telah terdistribusi normal maka pengujian selanjutnya menggunakan statistik parametrik yaitu pengujian dengan menggunakan uji Repeated Measures ANOVA sedangkan pada uji normalitas data tidak terdistribusi normal maka pengujian selanjutnya menggunakan statistik non parametrik yaitu Freidman. perhitungan uji 
normalitas data skor beban kerja mental dengan menggunakan software statistika SPSS 21 dapat diliat pada Tabel 4.4.

Tabel 6. Uji Normalitas Data Operator

\begin{tabular}{|l|l|l|}
\hline Kategori & Statistik Uji & Keputusan \\
\hline Shift Pagi & $0,518>0,05$ & Normal \\
\hline Shift Siang & $0,192>0,05$ & Normal \\
\hline Shift Malam & $0,760>0,05$ & Normal \\
\hline
\end{tabular}

Berdasarkan output uji normalitas pada Tabel 6distribusi data disebut normal bila distribusi data yang ada tidak berbeda signifikan yaitu $p$ value > $(0,05)$ yaitu pada derajat kemaknaan (alfa) 5\% atau 0,05. Berdasarkan Tabel 6 dapat dilihat di nilai signifikan Shapiro-Wilk. Nilai signifikan ini dipilih karena sampel yang digunakan kurang dari 50 sampel. Ketiga subjek dapat dikategorikan normal karena nilai $\mathrm{p}$ value $>\mathrm{a}$ $(0,05)$, yaitu nilai shift pagi $0,518>0,05$, shift siang $0,192>0,05$, shift malam $0,760>0,05$.

\section{Uji Repeated Measures ANOVA}

Uji Repeated Measures ANOVA dilakukan pada nilai lebih dari dua kelompok yang berpasangan. Uji ini bisa digunakan pada pengukuran yang dilakukan berulang kali terhadap variable dependent pada kondisi atau waktu yang berbeda. Pengujian Repeated Measures ANOVA dilakukan untuk mengetahui pengaruh shift kerja terhadap beban kerja mental operator boiler di area distributed control system (DCS). Pengujian dengan menggunakan RM-ANOVA harus mempertimbangkan tes sebelum menarik kesimpulan adalah dengan menganalisis nilai sperisitas dari pengujian menggunakan software statistika SPSS 21. Setelah melakukan pengujian dengan menggunakan software statistika SPSS 21 maka didapat output sperisitas pada Tabel 7.

Tabel 7. Hasil Tes Sperisitas

\begin{tabular}{|c|c|c|}
\hline $\begin{array}{c}\text { Within Subjects } \\
\text { Effect }\end{array}$ & Sig & Keputusan \\
\hline Waktu (Shift) & 0,893 & Tidak signifkan \\
\hline
\end{tabular}

Kriteria pengujian berdasarkan Tabel 7 tolak H0 jika hasil p-value dari sig < 0,05, yang berarti bahwa tidak ada perbedaan yang signifikan antar kombinasi kondisi dan waktu, dengan kata lain bahwa kondisi Sphericity tidak ditemukan. Jika tes Mauchly dan Sphericity tidak signifikan, maka tes Within-subject effects dapat dilakukan. Sedangkan jika tes Mauchly dan Sphericity signifikan, tes multivariat yang digunakan. Dapat dilihat pada Tabel 7 nilai sig $>(a=0,05)$ atau $0,893>0,05$ maka dapat diartikan varians perbedaan antar kombinasi seluruh waktu shift yang terkait sama atau tidak perbedaan yang signifikan, maka dapat disimpulkan data memenuhi syarat sperisitas.

Berdasarkan perhitungan menggunakan SPSS 21 tersebut, karena syarat sperisitas terpenuhi maka dapat mengggunakan nilai Huynh-Feldt digunakan untuk memperkuat keputusan dan analisa perbedaan signifikansi antar varian. Nilai Huynh-Feldt dapat dilihat pada tabel Tests of Whithin-Subjets Effects Output perhitungan yang telah dilakukan yang bisa dilihat pada Gambar 8.

Tabel 8. Tests of Whithin-Subjets Effects.

\begin{tabular}{|l|c|l|l|l|}
\hline \multicolumn{2}{|l|}{ Source } & Df & Sig & Keputusan \\
\hline Waktu & $\begin{array}{c}\text { Huynh- } \\
\text { Feldt }\end{array}$ & 2.000 & 0.150 & $\begin{array}{c}\text { Tidak } \\
\text { Signifikan }\end{array}$ \\
\hline
\end{tabular}

Melihat nilai Huynh-Feldt pada nilai $\mathrm{p}=0,150$ atau dapat dikatakan nilai $p>0,05$ dengan derajat kemaknaan $a$ (alfa) 5\% atau 0,05 maka berdasarkan hasil Repeated Measures ANOVA ini diketahui tidak ada perbedaan yang signifikan diantara varians perbedaan tiap kondisi kerja yaitu shift pagi, shift siang, dan shift malam. Langkah selanjutnya untuk mengetahui beban kerja mental operator boiler PT.Cahaya Fajar Kaltim pada masing-masing kondisi shift kerja yaitu shift pagi, shift siang dan shift malam dengan menggunakan tabel Pairwise Comparisons. Tabel ini mengggunakan pendekatan Bonferroni.

Tabel 9. Hasil Pairwise Comparisons

\begin{tabular}{|l|l|r|r|r|}
\hline $\begin{array}{l}\text { (I) } \\
\text { Waktu }\end{array}$ & $\begin{array}{l}\text { (J) } \\
\text { Waktu }\end{array}$ & $\begin{array}{c}\text { Mean } \\
\text { Difference } \\
(\mathbf{I}-J)\end{array}$ & $\begin{array}{l}\text { Std. } \\
\text { Error }\end{array}$ & Sig. $^{\text {a }}$ \\
\hline 1 & 2 & 6.557 & 5.623 & 0.831 \\
\hline & 3 & -4.630 & 4.925 & 1.000 \\
\hline 2 & 1 & -6.557 & 5.623 & 0.831 \\
\hline & 3 & -11.187 & 5.711 & 0.258 \\
\hline 3 & 1 & 4.630 & 4.925 & 1.000 \\
\cline { 2 - 5 } & 2 & 11.187 & 5.711 & 0.258 \\
\hline
\end{tabular}

Berdasarkan hasil hipotesis tersebut pada uji post hoc maka didapatkan 3 kombinasi untuk 
menentukan kondisi kerja yang paling tinggi dan paling rendah. 3 kombinasi tersebut dapat dijabarkan sebagai berikut:

1. Nomor 1 (kondisi shift 1 pagi) dibandingkan dengan nomor 2 (kondisi shift 2 siang) nilai rata-rata beban kerja mental yang terjadi pada operator bolier turun sebesar 6,557.

2. Nomor 1 (kondisi shift 1pagi) dibandingkan dengan nomor 3 (kondisi shift 3malam) nilai rata-rata beban kerja mental yang terjadi pada operator bolier naik sebesar 4,630.

3. Nomor 2 (kondisi shift 2siang) dibandingkan dengan nomor 3 (kondisi shift 3 malam) nilai rata-rata beban kerja mental yang terjadi pada operator bolier naik sebesar 11,187.

Berdasarkan hasil output maka dapat disimpulkan bahwa tidak ada pengaruh shift kerja terhadap beban kerja mental operator boiler PT. Cahaya Fajar Kaltim meskipun terdapat perbedaan nilai rata-rata pada pengujian Post Hoc Test bahwa shift malam memperoleh beban kerja mental palin tingggi, kemudian shift pagi mendapatkan beban kerja tertingggi kedua, dan shift siang memperoleh beban kerja mental terendah. Hasil kesimpulan ini didapat berdasarkan pengujian Post Hoc Test dengan melihat tabel pairwise comparisons

\section{Analisis Beban Kerja Mental}

Guna menganalisis pengaruh shift terhadap beban kerja yang dirasakan oleh operator boiler perlu adanya analisis pada masing-masing kondisi.

\section{Analisis Beban Kerja Mental Shift 1 (Pagi)}

Shift pagi merupakan shift pertama. Perhitungan nilai rata-rata skor yang didapat maka dapat dikategorikan pada kondisi 1 shift pagi, beban mental yang terjadi dapat dikatakan tinggi, diantara 50 sampai 79. Kategori ini didapatkan dari nilai sebesar 55,89 .

Pada pagi hari, para operator dituntut untuk konsentrasi penuh guna memantau dan mengawasi proses produksi yang sedang berlangsung.Berdasarkan hasil wawancara,shift pagi merupakan waktu awal menjalankan aktifitas dan tuntutan performansi yang harus maksimal. Seperti yang dijelakan oleh Rodahl (1989) dalam Tarwaka (2011), beban kerja dan kapasitas kerja dipengaruhi oleh berbagai faktor yang sangat komplek, baik faktor internal maupun faktor eksternal. Selain faktor yang dirasakan oleh operator beban kerja juga dapat dipengaruhi faktor-faktor lain seperti lamanya waktu kerja, waktu istirahat, kerja bergilir, kerja malam, sistem pengupahan, sistem kerja, model struktur organisasi, pelimpahan tugas, tanggung jawab, wewenang. Seperti yang diketahui bahwa operator 3, 6 dan 9 merupakan operator yang senior sehingga tuntutan tugas dan tanggung jawab yang diberikan juga semakin banyak, hal seperti inilah yang menjadi salah satu penyebab terjadinya beban kerja mental. Kurangnya pelatihan kerja juga menjadi penyebab terjadinya beban kerja mental, untuk menjadi seorang operator boiler banyak keahlian yang harus dimiliki baik kemampuan analisa dan pelatihan kerja. Berdasarkan analisa lapangan pelatihan kerja yang dilakukan oleh manajemen sangatlah kurang dalam menyediakan pelatihan kerja baik secara K3 maupun pelatihan keahlian kontroling ketel uap (boiler). Sesuai panduan dalam buku Nurmianto (2010) dalam standar internasional bagi pekerja yang membahas mengenai kesehatan dan keselamatan, bahwa setiap pekerja berhak mendapatkan kesempatan pelatihan kerja yang dapat berguna dalam pekerjaanya.

\section{Tabel 10. Nilai Indikator NASA-TLX pada Shift Pagi}

\begin{tabular}{|l|c|}
\hline \multicolumn{1}{|c|}{ Nama Operator Boiler } & Jumlah Indikator \\
\hline Kebutuhan Mental (KM) & 1930 \\
\hline Kebutuhan Waktu (KW) & 1195 \\
\hline Kebutuhan Fisik (KF) & 1640 \\
\hline Performansi (P) & 500 \\
\hline Tingkat Frustasi (TF) & 500 \\
\hline Tingkat Usaha (TU) & 1780 \\
\hline
\end{tabular}

Berdasarkan Tabel 10 dapat dijabarkan bahwa nilai indikator yang paling dirasakan oleh operator boiler pada saat bekerja pada kondisi kerja shift pagi adalah indikator beban kerja Kebutuhan Mental (KM). Kebutuhan mental sendiri merupakan seberapa tinggi aktivitas mental dan perceptual dibutuhkan misalnya berpikir, memutuskan, menghitung, menghapal, melihat, dan mencari. Apakah tugas tersebut sederhana atau kompleks, mudah atau sulit yaitu sebesar 1930. Dengan aktifitas kontroler yang banyak maka operator dituntut untuk menyiapkan kesehatan nya lebih baik guna mendukung tingkat konsentrasi yang lebih tinggi. Sebagai seorang operator di area Distributed Control System (DCS) harus memiliki kemampuan 
analisa dan memberi keputusan yang tepat dalam mengontrol jalannya produksi khususnya dalam operasi pembakaran atau boiler.

\section{Analisis Beban Kerja Mental Shift 2 (Siang)}

Berdasarkan hasil pengukuran yang telah dilakukan pada shift siang dapat disimpulkan rata-rata beban kerja yang dirasakan agak tinggi. Shift kedua merupakan shift siang, perhitungan nilai rata-rata skor yang didapat maka dapat dikategorikan beban mental yang terjadi dapat dikatakan agak tinggi, diantara 30 sampai 49. Kategori ini didapatkan dari nilai sebesar 49,41. Padashift siang hari para operator operator dituntut untuk konsentrasi penuh, guna memantau dan mengawasi proses produksi yang sedang berlangsung. Namun berdasarkan analisa beban kerja ada penurunan beban kerja karena pada shift siang operator telah mempersiapkan kondisi tubuh di pagi hari untuk dapat bekerja pada siang harinya. Operator lebih banyak menghabiskan waktu untuk memantau kalancaran bahan baku batu bara yang akan mengalami pembakaran. Dengan kata lain beban kerja yang terjadi dapat berkurang. Dikondisi siang operator perlu tanggap dalam menghadapi trauble atau masalah yang sedang terjadi di lapangan. Operator DCS khususnya boiler harus bisa memutuskan dengan tepat jika terjadi suatu kerusakan. Operator harus bisa berkomunikasi dengan lancar dengan pengawas lapangan untuk dapat memutuskan keputusan yang tepat jika disituasi yang genting. Operator juga harus tanggap jika terjadi kerusakan atau masalah di area lokal Distributed Control System (DCS). Namun jika dibandingkan dengan shift pagi, pada shift siang beban aktivitas kontroler jauh berkurang, namun pengawasann dan pemantauan terus dilakukan. Kurangnya kegiatan penunjang interaksi sosial juga menjadi penyebab terjadi beban kerja mental yang dirasakan oleh operator. Menurut Nurmianto (2004) bahwa permasalahan pokok yang berhubungan dengan shift kerja adalah terkadang pekerja tidur saat kegiatan sosial berlangsung. Sebagai perusahaan yang berproduksi selama 24 jam PT. Cahaya Fajar Kaltim hanya memiliki sedikit fasilitas dan prasarana seperti kegitan yang dapat menyehatkan tubuh.

\section{Tabel 11. Nilai Indikator NASA-TLX pada Shift Siang}

\begin{tabular}{|l|c|}
\hline \multicolumn{1}{|c|}{ Nama Operator Boiler } & Jumlah Indikator \\
\hline Kebutuhan Mental (KM) & 1320 \\
\hline Kebutuhan Waktu (KW) & 1375 \\
\hline Kebutuhan Fisik (KF) & 1165 \\
\hline Performansi (P) & 770 \\
\hline Tingkat Frustasi (TF) & 520 \\
\hline Tingkat Usaha (TU) & 1520 \\
\hline
\end{tabular}

Berdasarkan Tabel 11 dapat dijabarkan bahwa nilai indikator yang paling dirasakan oleh operator boiler pada saat bekerja pada kondisi kerja shift siang adalah indikator beban kerja tingkat usaha (TU). Tingkat usaha merupakan seberapa besar usaha yang harus dikeluarkan secara mental dan fisik yang dibutuhkan untuk mencapai tingkat performansi yang telah anda capai yaitu sebesar 1520. Dengan aktifitas kontroler yang banyak maka operator dituntut untuk menyiapkan kebugarannya tubuh lebih baik guna mendukung tingkat konsentrasi yang lebih tinggi. Sebagai seorang operator di area Distributed Control System (DCS) harus memiliki kemampuan analisa dan memberi keputusan yang tepat dalam mengontrol jalannya produksi khususnya dalam operasi pembakaran atau boiler dan operator harus tanggap jika terjadi masalah yang ada di lokal area DCS. Proses ini merupakan proses yang sangat vital dan yang utama, hal ini karena uap yang dihasilkan untuk memutar turbin dan generator dihasilkan dari proses ini.

\section{Analisis Beban Kerja Mental Shift 3 (Malam)}

Berdasarkan hasil pengukuran yang telah dilakukan pada shift malam dapat disimpulkan rata-rata beban kerja yang dirasakan tinggi tinggi. Berdassarkan hasil wawanara pada shift malam banyak faktor yang mempengaruhi terjadinya beban kerja mental. Operator merasa bahwa pada shift malam lebih berat menjalankan operasi dan mengontrol sistem karena rasa kantuk yang dirasakan. Dari sisi lain operator juga merasakan bahwa kondisi badan pada malam hari tidak prima, seperti badan lesu dan penglihatan pada malam hari terbatas. Sering kali pada shift malam jam istirahat yang seharusnya diberikan oleh operator tidak terjadwal dengan baik, sehingga berimbas kepada kondisi tubuh operator dalam bekerja. 
Tabel 12. Nilai Indikator NASA-TLX pada Shift Malam

\begin{tabular}{|l|c|}
\hline \multicolumn{1}{|c|}{ Nama Operator Boiler } & Jumlah Indikator \\
\hline Kebutuhan Mental (KM) & 2135 \\
\hline Kebutuhan Waktu (KW) & 1265 \\
\hline Kebutuhan Fisik (KF) & 1245 \\
\hline Performansi (P) & 845 \\
\hline Tingkat Frustasi (TF) & 1235 \\
\hline Tingkat Usaha (TU) & 1445 \\
\hline
\end{tabular}

Berdasarkan Tabel 12 dapat dijabarkan bahwa nilai indikator yang paling dirasakan oleh operator boiler pada saat bekerja pada kondisi kerja shift malam adalah indikator beban kerja Kebutuhan Mental (KM). Kebutuhan mental sendiri merupakan seberapa besar tuntutan aktivitas mental dan perceptual dibutuhkan dalam bekerja misalnya berpikir, memutuskan, menghitung, menghapal, melihat, dan mencari. Apakah tugas tersebut sederhana atau kompleks, mudah atau sulit yaitu sebesar 2135. Pada shift malam lebih berat menjalankan operasi dan mengontrol sistem karena rasa kantuk yang dirasakan. Dari sisi lain operator juga merasakan bahwa kondisi badan pada malam hari tidak prima, seperti badan lesu dan penglihatan pada malam hari terbatas. Sering kali pada shift malam jam istirahat yang seharusnya diberikan oleh operator tidak terjadwal dengan baik, sehingga berimbas kepada kondisi tubuh operator dalam bekerja.

\section{Pengaruh shift Kerja Terhadap Beban Kerja Mental}

Analisis pengaruh shift kerja terhadap beban kerja mental ini dilakukan terhadap hasil pengolahan data yang telah dilakukan terhadap seluruh operator boiler unit 3 PT. Cahaya Fajar Kaltim. Analisis ini dilakukan untuk mengetahui perbandingan masing-masing kondisi kerja atau shift kerja terhadap beban kerja yang timbul. Hasil yang peroleh dari pengukuran beban kerja mental dapat dlihat pada Tabel 13.

\section{Tabel 13. Perbandingan Beban Kerja Masing-masing Kondisi.}

\begin{tabular}{|c|c|c|}
\hline $\begin{array}{c}\text { Perbandingan } \\
\text { Kondisi Kerja (shift) }\end{array}$ & $\begin{array}{c}\text { Statistik } \\
\text { Uji }\end{array}$ & Keputusan \\
\hline Shift 1 dibandingkan & $0,831>$ & Tidak \\
shift 2 & 0,05 & signifikan \\
\hline Shift 1 dibandingkan & $1,000>$ & Tidak \\
shift 3 & 0,05 & signifikan \\
\hline Shift 2 dibandingkan & $0,258>$ & Tidak \\
shift 3 & 0,05 & signifikan \\
\hline
\end{tabular}

Berdasarkan nilai perhitungan dan pengujian yang telah dilakukan maka dapat dikatakan bahwa kondisi pada masing-masing shift tidak berpengaruh terhadap beban kerja mental yang dirasakan operator. Analisis ini didasarkan pada hasil uji statistika Repeated Measures Anova pada masing-masing shift kerja yang dapat dijabarkan sebagai berikut:

1. Kondisi shift 1pagi dibandingkan dengan kondisi shift 2 siang sebesar $0,831>0,05$ maka dapat disimpulakan tidak ada perbedaan yang signifikan diantara kedua kondisi.

2. Kondisi shift 1pagi dibandingkan dengan kondisi shift 3malam sebesar $0,831>0,05$ maka dapat disimpulakan tidak ada perbedaan yang signifikan diantara kedua kondisi.

3. Kondisi shift 2 pagi dibandingkan dengan kondisi shift 3 malam sebesar $0,831>0,05$ maka dapat disimpulakan tidak ada perbedaan yang signifikan diantara kedua kondisi.

Sesuai dengan hasil uji statistika menyebutkan bahwa pada antar ketiga shift tidak ada pengaruh yang signifikan. Hal ini terjadi karena dilihat dari data operator boiler masa kerja dari kesembilan operator boiler rata-rata telah bekerja lebih dari 1 tahun, sehingga membuat para operator telah terbiasa dengan sistem shift pekerjaan yang telah diterapkan oleh perusahaan dan pekerjaan yang diberikan menyesuaikan dengan kondisi shift. Hal ini sejalan dengan penelitian Pongoh dkk (2015) bahwa walaupun pekerja dihadapkan pada kondisi yang terancam atau sulit, hal itu tidak akan menyulitkan pekerja karena para pekerja sudah terbiasa dengan hal yang demikian karena mereka telah terlatik. Namum meskipun tidak ada pengaruh yang signifikan berdasarkan pengukuran beban kerja mental menggunakan NASA-TLX operator merasakan beban kerja mental saat bekerja, yaitu pada shift pagi sebesar 55,89 , kemudian beban kerja mental pada shift siang turun sebesar 49,41 dengan kata lain beban kerja yang terjadi dapat berkurang dibandingkan shift pagi dan naik pada shift malam sebesar 60,52 .

\section{Usulan Perbaikan}

Usulan perbaikan merupakan salah satu solusi dari permasalahan yang dianggkat dalam penelitian ini sehingga terciptalah kinerja yang 
lebih baik dari sebelumnya adalah sebagai berikut:

Tabel 14. Usulan Perbaikan

\begin{tabular}{|c|c|c|c|}
\hline No & Permasahan & $\begin{array}{c}\text { Landasasan } \\
\text { Perbaikan }\end{array}$ & Usulan Perbaikan \\
\hline 1 & $\begin{array}{l}\text { Penggunaan } \\
\text { pola shift yang } \\
\text { panjang, } \\
\text { dengan } 4 \text { hari } \\
\text { kerja dan } 2 \\
\text { hari long shift }\end{array}$ & $\begin{array}{l}\text { Rotasi shift yang } \\
\text { baik 2-2-2 } \\
\text { (metropolitas } \\
\text { pola) atau 2-2-3 } \\
\text { (continental } \\
\text { pola) Eko } \\
\text { Nurmianto } \\
(2004) \text {. }\end{array}$ & $\begin{array}{l}\text { Penerapan sistem shift } \\
\text { baru bagi perator } \\
\text { dengan pola } 2-2-2 \\
\text { atau 2-2-3, yaitu } 2 \\
\text { pagi, } 2 \text { siang dan } 2 \\
\text { malam }\end{array}$ \\
\hline 2 & $\begin{array}{l}\text { Kurangnya } \\
\text { kegiatan } \\
\text { penunjang } \\
\text { interaksi sosal } \\
\text { antar operator } \\
\text { dan } \\
\text { lingkungan. }\end{array}$ & $\begin{array}{l}\text { Sediakan waktu } \\
\text { sebanyak } \\
\text { mungkin untuk } \\
\text { kehudupan } \\
\text { keluarga dan } \\
\text { kontak sosial } \\
\text { Eko Nurmianto } \\
(2004) \text {. }\end{array}$ & $\begin{array}{l}\text { Pembangunan fasiltas } \\
\text { dan prasarana } \\
\text { pendukung untuk } \\
\text { memberikan kegiatan } \\
\text { yang positif kepada } \\
\text { operator. }\end{array}$ \\
\hline 3 & $\begin{array}{l}\text { Kurangnya } \\
\text { jam istirahat } \\
\text { yang didapat } \\
\text { oleh para } \\
\text { operator ketika } \\
\text { bekerja. }\end{array}$ & $\begin{array}{l}\text { Memenuhi jam } \\
\text { kerja istirahat, } \\
\text { berupa makan } \\
\text { dan istirahat Eko } \\
\text { Nurmianto } \\
(2004)\end{array}$ & $\begin{array}{lr}\text { Menyediakan } & \text { jam } \\
\text { istirahat dan } & \text { tempat } \\
\text { istirahat } & \text { yang } \\
\text { memadai } & \text { bagi } \\
\text { operator } & \end{array}$ \\
\hline 4 & $\begin{array}{l}\text { Minimnya } \\
\text { pelatihan } \\
\text { kerja, baik } \\
\text { pelatihan } \\
\text { keahlian } \\
\text { khusus dan } \\
\text { pelatihan (K3) }\end{array}$ & $\begin{array}{l}\text { Para pekerja } \\
\text { dengan pola shit } \\
\text { wajib untuk } \\
\text { mendapatkan } \\
\text { kesempatan } \\
\text { pelatihan kerja } \\
\text { Eko Nurmianto } \\
(2004)\end{array}$ & $\begin{array}{l}\text { Memberikan } \\
\text { pelatihan keamanan } \\
\text { kerja yang rutin, } \\
\text { pelatihan keahlian } \\
\text { khusus dan pelatihan } \\
\text { (K3) }\end{array}$ \\
\hline
\end{tabular}

Berdasarkan tabel usulan perbaikan tersebut maka dapat diuraikan adalah sebagai berikut:

1. Menerapan Sistem Shift yang Baru.

Penerapan sistem shift yang baru bagi operator boiler perlu dipertimbangkan oleh perusahaan. Menurut Nurmianto (2004), ada 2 sistem kerja yang dapat digunakan bagi para pekerja dengan menggunakan pola 2-2-2 atau 2-2-3. Hal ini diperkuat dengan hasil wawanara management idealnya menggunakan 4 grup dengan 3 shift, yaitu dengan pola kerja 8 jam setiap harinya yaitu 2 pagi, 2 sore, 2 malam, dan 2 istirahat yang memiliki hubunganya dengan kesehatan pekerja. Penerapan grup kerja ini bertujuan untuk memberi waktu istirahat yang cukup bagi para operator, sehingga dengan waktu yang tercukupi operator dapat mempersiapkan kondisi tubuh lebih baik dan berpengaruh terhadap konsentrasi yang dibutuhkan dalam menjalankan tugas sebagai pengawas dan kontroler boiler.

2. Pembangunan Fasilitas dan Prasarana Pendukung.
Pembangunan fasilitas dan prasarana pendukung berguna untuk memfasilitasi para pekerja PLTU Embalut di PT. Cahaya Fajar Kaltim dalam memberi kegiatan yang positif. Salah satu contoh pembangunan fasilitas guna menunjang kinerja dan menekan terjadinya beban kerja mental adalah dengan membangun fasilitas untuk kebugaran jasmani Kebugaran jasmani membuat para pekerja dapat melupakan sejenak rutinitas pekerjaan yang dilakukan khususnya sebagai operator boiler. Pihak manajemen telah menanggapi permasalahan dan telah membangun beberapa fasilitas seperti lapangan tenis dan pengadaan alat-alat fitness namun tidak berhenti dari situ perusahaan terus mengembangkan sarana dan fasilitas dengan membangun gedung olahraga yang masih dalam proses pembangunan yang meliputi lapangan bulutangkis, lapangan futsal, dan lapangan sepak bola.

3. Menyediakan Jam Istirahat yang Memadai Menurut Nurmianto (2004) menyediakan jam istirahat yang memadai merupakan salah satu cara yang tepat guna merekomendasi usulan dari beban kerja yang dirasakan oleh operator. Hal ini sejalan dengan yang dirasakan operator dan hasil wawancara, operator masih belum mendapatkan waktu istirahat yang sesuai dan teratur. Tidak teraturnya jam istirahat operator disebabkan tempat istirahat di area DCS yang minim, sehingga operator tidak mendapatkan jam istarahat yang cukup.

4. Memberikan Pelatihan Keamanan Kerja yang Rutin

Pelatihan keamanan kerja merupakan salah satu aspek penting dalam bekerja. Menurut Nurmianto (2004), operator wajib mendapatkan pengetahuan yang lengkap mengenai pelatihan kerja. Beban kerja mental yang terjadi dapat diminimalisir dengan pengetahuan yang banyak mengenai keselamatan dan kesehatan kerja (K3).

\section{Kesimpulan dan Saran Kesimpulan}

1. Beban kerja mental yang dirasakan oleh operator boiler PLTU Embalut PT. Cahaya Fajar Kaltim berdasarkan metode NASA-TLX didapat pada shift pagi termasuk ke dalam kategori beban kerja mental tinggi dengan nilai skor sebesar 55,89, pada shift siang termasuk ke dalam kategori beban kerja 
mental agak tinggi dengan nilai skor sebesar 49,41, dan pada shift malam termasuk ke dalam kategori beban kerja mental tinggi dengan nilai skor sebesar 60,52.

2. Berdasarkan hasil uji statistik Repeated Measures ANOVA maka dapat disimpulkan bahwa tidak ada pengaruh shift kerja terhadap beban kerja mental operator boiler PT. Cahaya Fajar Kaltimkondisi ditunjukkan melalui shift 1pagi dibandingkan dengan kondisi shift 2 siang sebesar $0,831>0,05$ maka dapat disimpulakan tidak ada perbedaan yang signifikan, kondisi shift 1pagi dibandingkan dengan kondisi shift 3malam sebesar $0,831>0,05$ maka dapat disimpulakan tidak ada perbedaan yang signifikan, dan kondisi shift 2 pagi dibandingkan dengan kondisi shift 3 malam sebesar $0,831>0,05$ maka dapat disimpulakan tidak ada perbedaan yang signifikan diantara kedua kondisi.

3. Usulan perbaikan berupa rekomendasi dapat diberikan terhadap hasil nilai perhitungan dan analisa beban kerja mental operator boilerDistributed Control System (DCS) PLTU Embalut di PT.Cahaya Fajar Kaltim yaitu dengan penambahan menerapan sistem shift yang baru., menyediakan tempat istirahat yang memadai, pembangunan fasilitas dan prasarana pendukung, dan memberikan pelatihan keamanan kerja yang rutin.

\section{Saran}

1. Penelitian ini dapat digunakan sebagai refrensi serta dapat dikembangkan dengan mengukur beban kerja mental di unit area DCS yang lain yaitu unit 1 dan unit 2 di PLTU Embalut PT. Cahaya Fajar Kaltim serta dapat mengukur beban kerja mental secara objektif alat pengukuran lainya, dan

2. Usulan perbaikan yang di susun dapat dipertimbangkan oleh pihak perusahaan PT.Cahaya Fajar Kaltim guna meminimalisasi beban kerja mental operator boiler.

\section{DAFTAR PUSTAKA}

1. Annafi, H., Soedjatmiko, dan Sumaryono, S., Interface Pengendalian Level dan Tekanan Dengan Distributed Control System, Jurnal Penelitian Teknik Elektro, Vol. 3 No. 4,2010, Desember, Bandung.
2. Grandjean, E., 1986, Fitting The Task to The Man: An Ergonimics Approach, Philadelphia, Taylor Francis.

3. Hancock, P. A., Meshkati, N., 1988, Human Mental Workload. University Of South California. CA.

4. Hard, S.G., 2006, Nasa-Task Load Index (Nasa-Tlx);20 years later, Procedings of the human factors and Ergonomics Society 50th Annual Meeting, 904-908, 2006, Moffet Field, CA.

5. Nurmianto, E, 2004. Ergonomi: Konsep Dasar dan Aplikasinya, Teknik Industri-ITS, Surabaya.

6. Pongoh, V.V., Warouw, H., dan Hamel, R., Perbedaaan Strees Kerja Antar Shift Perawatan di Ruagan Gawat Darurat Medik RSUP Prof DR. R. D. Kandau, e-jurnal, Vol. 3 No. 2, 2015, Manado.

7. Suaib, 2011, Ulasan Analisis Varian Bagi Pengukuran Berulang Analysis Of Variance Of Repeated Measures, Jurnal Agroteknos, Vol. 1 No.2. ISSN 2087-7706, Kendari.

8. Tarwaka, 2011, Ergonomi Industri, Dasardasar Pengetahuan Ergonomi dan Aplikasi di Tempat Kerja, Cetakan kedua, UNIPRESS, Surakarta.

9. Wignjosoebroto, S.., 2006, Ergonomi Studi Gerak dan Waktu, Guna Widya. Surabaya. 